consciousness at the same time. The experience of digital socio-cultural practices tells us that this environment is quite favorable for the formation of the subject field of new scientific disciplines, for the formation and approval of new types of art as ways of self-realization of the personality of everyone, fully included in the digital noosphere. Conclusions. As you know, social progress always has two sides. In the case of the formation of the extremely formalized environment, which is discussed in this article, we observe both positive and negative trends. This is expressed in the desire to ensure the coadaptation of two natural antipodes - human and artificial intelligence. Their main difference is, first, in their origin, and, secondly, in the ways of solving problems of any complexity. Algorithmic and mathematical, that is, the discrete nature of artificial intelligence come into conflict with the intuitiveness, emotionality and spirituality of human intelligence. Thus, the ideas of transhumanism, in the form and context in which they are preached, need correction. Renaissance 2.0 (neuro-digital) can take place only if the classical traditions of anthropocentrism are observed. This will ensure real and not imaginary social progress in the 21 st century.

Keywords: cybersocium, socio-cultural practices, digital noosphere, discreteness, continuity, singularity, reflexive formalization.

UDC $1(091)$

L. Drotianko ${ }^{1}$, S. Yahodzinskyi ${ }^{2}$

\title{
DIGITALIZATION OF EDUCATIONAL ENVIRONMENT: TENDENCIES AND PERSPECTIVES
}

\author{
National Aviation University \\ 1orcid.org/0000-0001-7041-5787 \\ 2orcid.org/0000-0001-8755-2235
}

\begin{abstract}
The paper discusses formation of virtual educational environment. Analysis of development of information networks and online education services pointed out that the main tendency in today's education is digitalization. Despite advantages of innovative technologies, the system of global information networks will be less efficient without realization of sociocultural potential. In accordance with concepts of actor-network theory educational environment of information society consists of educational process participants as well as technological devices, communication systems, databases, distance learning systems, etc.
\end{abstract}

Keywords: information network, educational environment, digitalization, actor-network theory, virtualization.

\section{Introduction}

According to leading analyst companies there are about 4 billion active users and more that billion websites on the Internet. On the one hand, it makes people closer and encourages open communication, knowledge becomes more accessible. On the other hand, philosophers, sociologists and political analysts noticed negative impact of Innovative gadgets and technologies.

Considering these tendencies, we absolutely agree with the idea introduced by F. Girenok in a cycle of his works. He calls the state of the present an anthropological catastrophe, whereas the contents, velocity and fluidity of events leave no space for a human to co-exist with others. Under such conditions, 'communication is only the means of co-existence with time, with the conditional, with the partial' (Girenok, 2008: 29). The desire to meet the needs of the age, to be relevant, urgent transforms society into a network system with no element being in the quiescent state; therefore, the social structure becomes temporal, virtual.

\section{The aim and tasks}

At the same time, absence of rules prevents global expansion of technology that immediately causes fail of a resource. There are a sufficient number of examples proving this dependence. Indeed, complicated rules of editing Wikipedia pages resulted in steep decrease of interest in filling this socially important resource. Consequently, the founder of the open accessible encyclopedia J. Wales was forced to admit that the strict policy concerning contents of pages had yielded a reverse effect. Wikipedia and Wikimedia are becoming outdated sources of information, whereas they are not getting updated at the pace that was observed during the previous stages of their development. History of formation and operation of information networks has proved numerous times verity of the statement that a user usually sacrifices the contents, but not the form. This thesis leads us to the necessity of analyzing architecture of global information networks which can't be reduced to neither formal nor conceptual component of the network as a structure.

\section{Research methods}

A significant amount of both scientific, scientificpublicist and popular literature is dedicated to the issues of educational space virtualization. To our opinion, one of the most profound studies raising the issue of transformation of the forms of individual and social existence is represented in the cycle of works by M. Nosov. Regarding the necessity and possibility of social-philosophical conceptualization of the phenomenon of the virtual, he writes: 'Virtualistics is a new worldview corresponding with this stage of civilization development - whereas not only the Western or the Eastern one, but any civilization on the Earth' (Nosov, 2001: 16). Such interpretation of virtuality allowed the author of the mentioned words to speak of the phenomenon of covirtuality (Nosov, 2000: 412-414) defining the simultaneous stay of people in the virtual space constructed under the single principles. Orientation at psychological aspects of transformation of social practices, unfortunately, did not cover the issue of reasons of virtual space formation.

Some scholars contend that innovative technologies in public life don't imply theoretical models, developed by Daniel Bell, Alvin Toffler, Peter Ferdinand Drucker and Yoneji Masuda. Dmytro Ivanov writes that computerization of public life spheres moves us away from information society. Nowadays theoretical knowledge still took leading position in the university. Indeed, theoretical knowledge was integrated into 
the capitalist mode of production. Projections of theoreticians failed to materialize, because they consider knowledge and information equal.

Which are effects of computerization? In the case of production as well as service sector mental labour outcompete physical one. Informatization encompassed scientific activity: knowledge spreads more rapidly due to computer technologies. This process is predominant in fundamental research as well as applied one.

The way of science communication has changed fundamentally. Information network Internet gives scholars opportunities to discuss scientific issues online, using an e-mail; receive the latest science news from scientific centers all around the world that allows to share scientific discoveries faster. Computerization of science implemented such types of scientific publications as electronic scientific journals, collection of scientific papers, multi- and single-author monographs, etc.

We should notice that founders of cybernetics and mathematical theory of communication (Claude E. Shannon, Norbert Wiener, John von Neumann, Alan Turing, Andrey Kolmogorov, etc) played a bigger role in formation of knowledge society than cultural studies scholars, futurologists and philosophers. They developed fundamentals of machine intelligence, which formed the basis for electronic computers and other devices to receive, process, relay and store large amounts of information. All of that aim at digitalization of educational environment.

In 50th of last century Norbert Wiener wrote that machines are able to improve themselves/"to learn", and it affects many spheres of public life, including education. Alan Turing and Andrey Kolmogorov explored mathematical aspects of designing of digital computer with unlimited storage. It supposed not only perform a lot of functions, but engage in music, painting, poetry instead of human (Nosov, 2001: 214312). Outstanding cyberneticists were interested in cognitive abilities of new computers as well as moral aspect of practical application.

Herbert Marshall McLuhan affirmed considerable impact of electronic technologies on social progress. $\mathrm{He}$ wrote that "technology shapes and changes social interdependence patterns and every aspect of our life" (Informatsionnoe obschestvo, 2004: 343). Scientist asserted that electronic technologies developed communication and put an end to psychical, social, economic and political isolation. People are able to take part in politics even at home. These facts confirm that digitalization will be a stream phenomenon for a couple of years.

Generalizing the definitions introduced in scientific literature, we will use the term 'informational architectonics of the global social space' to denote the logical-semantic system of creating and placing contents. At the same time, the word 'placing' should not be recognized as publishing contents in the network, but as a complex of measures taking into account program, hardware and human factors. In other words, informational architecture is a framework the global information environment is functioning on. Without the informational structure, its logical construction, an information environment turns into the set of texts, links, quotations, comments etc. In this form, it loses its heuristic, value, economic, political and sociocultural potential in general.

\section{Research results}

The necessity of creating informational education system is caused by objective reasons. Velocity of the course of global social processes and consolidation of space interactions demand an open access to information channels with tools of immediate (context) search, procession, translation, synchronization and archivation. For several years already, leading scientific, educational, government establishments, business corporations have been creating and improving systems which broaden the potential of innovative-communicational networks. In course of time, they created information environment integrating today into global information networks.

Under this scenario, global educational networks will be evolving during the nearest several years. Aggregation of today separate information environment and creation of a new informational architecture on their basis constitute a natural tendency of development of global information networks. The existing information networks are already following this scheme. Ignoration of integrative processes will further find its reflection at the level of both individual and social consciousness. In the 1970's the developer of the theory of cultural imperialism $\mathrm{H}$. Schiller wrote: 'Technical innovations resulting from significant expenses can be hardly recognized as random discoveries or autonomous phenomena' (Shiller, 1980: 249-250). Thus, trivial, superficial understanding of the mechanism of technical progress as qualitative propulsion provokes appearance of the feeling of personal helplessness and social bewilderment.

To illustrate the process of innovative technologies acquiring social features, we will present the history of creating a data base of Scopus scientific journals. The Elsevier private publishing house focused on creating an informational structure enabling scholars from all over the world to obtain a fast and reliable tool producing access to innovative scientific developments and results. For several years, the commercial project had turned into a global information network; the new network acquired characteristics which were not primarily inherent in the project. Indeed, inclusion of a scientific journal in this base is considered to prove the quality of its materials, whereas the presence of publications in Scopus journals is an obligatory condition for recognition of the status of a researcher as a productive scholar. The informational structure introduced by the developers turned out to be successful enough to incorporate separate, scattered, fragmented in networks scientific publications, collections, conference proceedings on all the relevant directions of scientific activity.

Consequently, universities, scientific-research establishments, educational centers and research societies are joining the Scopus base and creating a certain informational medium. At the same time, though the Scopus information network is a global one, it differs qualitatively from other networks on the Internet since the access to the data base is possible only 
under certain conditions. The latter are focused on preventing violation of the resource informational structure and on providing efficiency of its operation. The search system, evaluation, referee reports, relevancy, quotation indices and similar tools assure a user (a scholar, a PhD, a student, anybody interested in the issue) that the data conform to the scientific criteria.

The sociologist $R$. Burt called these networks translators of social capital since they contain mechanisms of the process of corresponding social capital and human capital (Burt, 2001). For these systems, in the informational epoch the thing that loses its value for a human is immediately transforming into a disincentive element of social development. Therefore, to our opinion, the hyperspace called the Internet network will gradually in course of time transform into the system of global information spaces. Within this context, we agree with the statement that the existing concepts of the information society are nothing more than theoretical constructs (Drotianko, 2011: 5-8). Within several aspects, these theories produce an only tangent and quite diagrammatic reflection of the present sociocultural situation. They can be applied to a limited part of social, cultural, political and economic problems of the modern stage of civilization development.

Therefore, regardless of the undeniable advantages of innovative technologies, their ability to immediately and comprehensively satisfy a broad complex of needs of a modern human, the system of global information networks will lose stability without detection and realization of a sociocultural potential embodied in it. Analyzing the prospects of development of innovative technologies, J. Kurose and K. Ross (developers of the principles of data packet switching) noted the tendency to self-regulation of global information networks (Kurose, 2013: 83). In 2003, the Internet would become a 'living' organism able to independently collect, process and spread information, and in prospect - to make decisions. Even today the number of individual contributions to the global information network is decreasing in percentage correlation due to the absence of demand on non-valid information sources. At the beginning of the 21st century a bigger part of traffic (transmitted and downloaded information) is already being generated by machines instead of human. Hence, in the nearest future the need in the single structure of an international network and common protocols (rules) of information environment operation will become the high priority objective of technology development.

These tendencies once again prove our thesis about virtualization of social (including educational) networks and their integration into the global informational space. However, such processes won't be completed without recognizing innovative communication technologies and technicaltechnological innovations as sociocultural phenomena. One of the factors preventing it constitutes, to our opinion, in a slightly disfigured and exaggerated idea about the phenomenon of virtualization. According to the just statement of D. Ivanov, appearance of the discourse 'emphasizing the contrast between old and new types of social organization on the basis of the notions "simulation of the real", "virtual reality", "cyberspace" etc. allows to claim that all authors operating with the distribution of the real and the virtual when analyzing social changes don't only experiment with the new metaphor, but also conceptualize the contingent movement of the end of the 20th beginning of the 21st centuries' (Ivanov, 2002: 143). This conceptualization enables to understand the issue of virtualization comprehensively following the single methodological foundations and notion-category base.

\section{Discussion}

At the same time, virtualization is often explained by processes which are neither directly nor indirectly connected to it. As a result, there is being established a disfigured idea about virtualization of social reality as about a process of transit from reality to simulacra and images. According to our opinion, the issue is not about images and not about their producing, but about the fact that they cause replacement of needs and interests of a human. Paying attention to virtual simulacra of real phenomena and processes is aimed at distracting society from the sociocultural potential of innovationnetwork technologies.

Within this context, we side with the position of representatives of the actor-network theory (G. Tarde, B. Latour, J. Law, J. Uri and others) who raised the issue of the necessity of rethinking and reconstructing of the phenomenon of the social. In particular, B. Latour believes it to be unjustified to limit sociality exclusively with the world of people since 'it is incomprehensible whether there exist specific enough relations to be called "social"... It is likely that the social in the dissolved form exists everywhere, and in the pure form - nowhere' (Latur, 2014: 12). From the point of view of classical social-philosophical concepts, the conclusion of representatives of the actor-network theory looks absurd: the social does not exist. The social is not people, groups, states, but a special type of connection between social agents, artifacts and even things.

Applying this idea to comprehension of globalization processes, A. Mol and J. Law write that the contents of the notion 'society' covers no more than a certain area of habitation of people whose customs, rites, norms make them differ from other groups of people (Mol, Law, 1994: 645-647). Actually, in the era of network community formation, society is to be recognized as a space of networks, streams, information channels. Breaking up with borders and limitations, such society develops its own intentions and the potential necessary for civilizational propulsion. One should admit that, under the conditions of operation of global information networks, the information environment is filled not only with people, but also with technical instruments, communicational systems, data bases etc. The mentioned, to our opinion, defines the contents of the notion of network social architectonics; we will address this notion a number of times within the process of conceptualizing the phenomenon of global information networks.

Considering this, we'll agree with the introduced notion of 'technological curtain' (Onoprienko, 2011: 21) used for denoting the next stage of development of the information society global economy. Its contents lie in the fact that developing countries, their economy, 
education, science are not able to master technological innovations. And because of the high cost of the latter they don't even have the access to opportunities of general course of the network of innovative information networks and their systems. Therefore, information environment of the Western countries are continual alternatively to discrete information environment of other countries. On one hand, this is a source of informational inequality, on the other hand - it is a mechanism of power, control and 'false' (M. Heidegger), separated from a human and his/her needs, globalization.

\section{Conclusions}

Following the mentioned, we may conclude that social transformations provoking development of information networks first of all affect the globalization of social space. At the same time, it is not homogenous and preserves irregularity corresponding to the economic plane. One of the brightest proofs of artificial inhibition and control of globalization processes was provided by the website of the Wikileaks informational resource. Its developers showed that technologically developed countries with the established efficient informational infrastructure of services are actually not ready to live in the single information environment with the other world. Simultaneously, they created all conditions and resources for efficient concentration of knowledge, technologies, data bases etc. acquired by the humanity. Consequently, the notion of 'golden billion countries' still preserves its status of a social phenomenon. Like it was in the previous epochs, the majority gets innovative tools, goods, information, knowledge and similar services only when these can't be used for social transformations anymore; when all the mentioned is subordinated structurally to a more accomplished informational system and doesn't exist out of it.

Therefore, the main educational digitalization trends are as follows: 1) lecturer in the role of mentor, coordinator, moderator of online and offline learning; 2) creating of education systems as systems of content administration; 3) interdisciplinarity and multispecialization of competency-based approaches to education.

Paying attention to the role of the informationaltechnological revolution in formation of contours of social reality of the late 20 th - early 21 st centuries, we've analyzed informational activity as an attribute of the Western world development. We believe that this revolution is not the last one and only prepares foundation for further sociocultural changes. Arguably, the information society will soon devour the innovative society which would bring biotechnological, homotechnical and socio-technological revolutions (Chumakov, 2005: 157). Refusing to predict such distant future, we may suppose that globalization of information networks which is actively progressing in both Western and Eastern countries is transforming in the short run the informational-technological evolution into the informational-communicational revolution.

\section{References}

1. Girenok, F. 2008. Udovolstvie myislit inache [The pleasure of thinking differently]. Moskva: Akademicheskiy Proekt.

2. Nosov, N.A. 2001. Manifest virtualistiki [Virtualist Manifesto]. Moskva: Put.

3. Nosov, N.A. 2000. Virtualnaya psihologiya [Virtual psychology]. Moskva: Agraf.

4. Shiller, G. 1980. Manipulyatoryi soznaniem [Mind manipulators]. Moskva: Myisl.

5. Burt, R. 2001. The Social Capital of Social Holes. New Directions in economic Sociology. N.-Y.: 201-246.

6. Drotianko, L.H. 2011. Informatsiinyi prostir i dialoh kultur v interieri KhKhl stolittia [Information space and dialogue of cultures in the interior of the 21st century]. Visnyk Natsionalnoho aviatsiinoho universytetu. Seriia: Filosofiia. Kulturolohiia. № 1 (13): 5-8.

7. Kurose, J., Ross, K. 2013. Computer Networking: A TopDown Approach. Boston: Addison-Wesley.

8. Ivanov, D.V. 2002. Imperativ virtualizatsii: Sovremennyie teorii obschestvennyih izmeneniy [The Imperative of Virtualization: Modern Theories of Social Change]. SPb.: Izd-vo S.-Peterb. un-ta.

9. Latur, B. 2014. Peresborka sotsialnogo: vvedenie $v$ aktorno-setevuyu teoriyu [Reassembling Social: An Introduction to Actor-Network Theory]. Moskva: Izd. dom Vyisshey shkolyi ekonomiki.

10. Mol, A., Law, J. 1994. Regions, Networks and Fluids: Anaemia and Social Topology. Social Studies of Science. Vol. 24 (№ 4): 641-671.

11. Onoprienko, V.I. 2011. Ponyatie «informatsionnaya bednost» v kontekste globalizatsii [The concept of "information poverty" in the context of globalization]. Visnyk Natsionalnoho aviatsiinoho universytetu. Seriia: Filosofiia. Kulturolohiia. № 1 (13): 19-22.

12. Chumakov, A.N. 2005. Globalizatsiya. Konturyi tselostnogo mira [Globalization. The contours of a holistic world] Moskva: TK Velbi; Izd-vo Prospekt.

13. Informatsionnoe obschestvo [Information society]. 2004. Moskva: AST, 2004

14. Shvab, K. 2019. Chetverta promyslova revoliutsiia. Formuiuchy chetvertu promyslovu revoliutsiiu [Fourth Industrial Revolution. Forming the fourth industrial revolution]. Kyiv: Klub simeinoho dozvillia.

\section{Л. Г. Дротянко, С. Н. Ягодзинский}

\section{ДИДЖИТАЛИЗАЦИЯ ОБРАЗОВАТЕЛЬНОГО ПРОСТРАНСТВА: ТЕНДЕНЦИИ И ПЕРСПЕКТИВЫ}

Рассмотрены вопросы формирования виртуальной образовательной среды. На основе анализа развития инфоормационных сетей и образовательных онлайн сервисов установлено, что тенденцией становления образования в ближайшие годы является ее диджитализация. Отмечается, что несмотря на преимущества инновационных технологий, система глобальных информационных сетей теряет стабильность без выявления и реализации заложенного в ней социокультурного потенциала. Опираясь на идеи представителей акторно-сетевой теории, авторы пришли к выводу о том, что образовательное пространство информационного общества заполняют не только участники образовательного процесса, но и технические устройства, коммуникационные системы, базы данных, системы дистанционного обучения и тому подобное.

Ключевые слова: информационная сеть, образовательное пространство, диджитализация, акторно-сетевая теория, виртуализация.

\section{Л. Г. Дротянко, С. М. Ягодзінський}

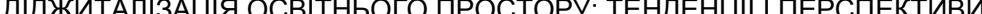

У вступі виявлено необхідність аналізу архітектури глобальних інформаційних мереж, яка не редукується ні до формальної, ні до змістовної складової мережі як структури. Показано, що пройдений соціумом етап комп'ютеризації робить можливою трансформацію освітнього простору з урахуванням ії діджиталізації. При формулюванні мети дослідження автори виходили з невирішеності питання причин, методів і підходів при формуванні віртуального простору сучасної освіти. Зважаючи на 
специфіку об'єкту дослідження, автори спиралися на системний та соціокультурних підходи, а також на методологічну базу акторно-мережевої теорії. В основні частині розглянуто питання формування віртуального освітнього середовища. На основі аналізу розвитку інформаційних мереж та освітніх онлайн сервісів виявлено, що тенденцією становлення освіти у найближчі роки є їі діджиталізація. Встановлено, що, попри переваги інноваційних технологій, система глобальних інформаційних мереж втрачатиме стабільність без виявлення і реалізації закладеного в неї соціокультурного потенціалу. Спираючись на ідеї представників акторно-мережевої теорії, автори отримали висновок про те, що освітній простір інформаційного суспільства заповнюють не лише учасники освітнього процесу, а й технічні пристрої, комунікаційні системи, бази даних, системи дистанційного навчання тощо. У висновках автори дійшли думки про те, що інформаційно-технологічна революція, а також процес діджиталізації як її прикладна складова не лише трансформують соціальну реальність, а й закладають підґрунтя для подальших соціокультурних змін. Сформульована гіпотеза про те, що глобалізація інформаційних мереж у короткостроковій перспективі провокуватиме інформаційно-комунікаційну революцію в глобальному масштабі.

Ключові слова: інформаційна мережа, освітній простір, діджиталізація, акторно-мережева теорія, віртуалізація.

УдК $164.041+165.412$

I. 3. Дуцяк

\title{
МЕРЕОЛОГІЧНА АКСІОМА ПРО ОБ'ЄДНАННЯ ЧАСТИН ІЗ ЦІЛИМ СУПРОТИ АПОРІї ЗЕНОНА "МІРА"
}

Національний університет "Львівська політехніка";

ORCID iD: 0000-0001-8751-4001; Idutsyak@gmail.com

\begin{abstract}
Анотація. У статmі викладено результати досліджень джерел суперечності в апорії Зенона “Міра”. Для здобуття шуканих знань виконано такі пізнавальні діі: проаналізовано приклад розділення на частини реального предмета; побудовану на цій основі модель розділення на частини зіставлено з моделлю розділення предмета заідно з апорією Зенона "Міра". На підставі виконаного зіставлення виявлено відмінності між згаданими моделями, які дали змогу виявити джерело суперечності. Обгрунтовано, що об'єднання частин предмета, утворених внаслідок його нескінченного розділення, не дає нескінченної кількості об'єктів. Для усунення суперечностей, що грунтуються на аналізованій апорії, сфрормульовано мереологічну аксіому об'єднання частин із цілим.
\end{abstract}

Ключові слова: апорія Зенона “Міра”, ціле, частина, нескінченна подільність, мереологія, аксіома.

\section{Вступ}

Сутність пізнавальної проблеми, яка вирішується, полягає в такому. Кожен предмет має ті чи інші лінійні розміри. Водночас, кожен предмет складений із частин, які, отже, мають менші лінійні розміри. Внаслідок нескінченної подільності предмета лінійні розміри частин повинні прямувати до нуля. Згадані лінійні розміри частин не можуть дорівнювати нулю, оскільки внаслідок об'єднання частин, які мають нульові лінійні розміри, неможливо отримати предмет із лінійними розмірами, більшими від нуля. Водночас, частини не можуть мати лінійні розміри, більші від нуля, адже після об'єднання нескінченної кількості частин із розмірами, більшими від нуля, буде отримано предмет із нескінченно великими лінійними розмірами. Отримуємо суперечність лінійні розміри частин предметів не можуть ані дорівнювати нулю, ані бути більшими від нуля. (Парадоксальним буде також висновок, що внаслідок нескінченного розділення якогось предмета зі скінченними лінійними розмірами отримують його частини, які мають у сумі нескінченно великі розміри).

Насамперед, доцільно почати з того, що частина авторів просто відкидають парадокси, не пояснюючи їхні джерела. Наприклад, Діоген, у відповідь на твердження про неможливість руху, встав і почав ходити. Треба відзначити, що демонстрація руху не була переконливим контраргументом. Адже траплялося так, що знання, отримані як продукт чуттєвого пізнання (але які, насправді, були наслідком узагальнень), виявлялися хибними, тому чуттєвий досвід не сприймався як переконливий аргумент. Як приклад можна навести пізнавальну ситуацію з більш пізнього періоду - узагальнення безпосереднього сприйняття спостережуваної поверхні як плоскої на всю Землю, яке виявилося пізніше хибним. Це знання сприймалося не як результат узагальнення, а як знання, дане органами відчуттів - адже ми бачимо, що Земля $є$ плоскою. (В цей час уже усвідомлювали відмінність між знанням і гадкою, яка може виявитися хибною). Тож емпіричне підтвердження, підтвердження, яке сприймають органами відчуттів, не приймалося як гарантія істинності.

До фрорм відкидання парадоксу можна віднести й інший варіант. Архімед продемонстрував можливість теоретичного опису руху відповідно до того, як він відбувається, описав рух за допомогою такої моделі, згідно з якою рух і починається, і завершується (на відміну від Зенонового опису руху). Одним із таких описів $\epsilon$ аксіома Архімеда (якщо тіло може переміститися на довільний відрізок, то якою б великою не була віддаль, її можна перевершити, повторюючи якусь кількість разів переміщення на згаданий відрізок). Архімед показав як можна математично описати рух у такий спосіб, щоб це відповідало дійсності, однак, як і Діоген, не пояснив джерел суперечності в міркуваннях Зенона.

Дослідниками апорії "Міра" відзначено, що вона $€$ концептуально близькою до апорій "Дихотомія" та "Ахіллес і черепаха" (Skyrms, 1983). Тому пошук спростувань кожної із цих трьох апорій $є$ водночас пошуком пояснення решти двох. Головні підходи до критики аналізованої апорії можна згрупувати в такі два напрями:

1. Заперечення нескінченної подільності. До прибічників такого розв'язання парадоксу можна віднести, насамперед, Левкіппа та Демокріта, які прийняли, що світ є складеним із неподільних атомів. До цієї групи треба віднести також прибічників поглядів, що в області мікросвіту, де є порційована (квантована) енергія, порційованими будуть також 